\title{
İlköğretim Okulu Yöneticilerinin Dağıtımcı Liderlik Davranışlarını Gösterme Düzeyleri ${ }^{27}$
}

\author{
Ebru Korkmaz \\ Yıldızeli Milli Eğitim Müdürlüğü, Karalar İlköğretim Okulu \\ Sivas / Türkiye \\ Doç. Dr. Hasan Basri Gündüz* \\ Yıldız Teknik Üniversitesi Sosyal Bilimler Enstitüsü, \\ Beşiktaş Merkez Yerleşkesi, Çukursaray Binası, 34349, Beşiktaş / İstanbul / Türkiye \\ hgunduz@yildiz.edu.tr
}

\begin{abstract}
Özet
Araştırmanın amacı, ilköğretim okul yöneticilerinin dağıtımcı liderlik davranışlarını gösterme düzeylerine yönelik öğretmen görüşlerini belirlemektir.

Araştırmada genel tarama modeli kullanılmıştır. Araştırmanın evreni Kocaeli il merkezindeki ilköğretim okullarında görev yapan öğretmenlerdir. Araştırmanın verileri Kouzes ve Posner (2001) tarafından geliştirilen Liderlik Davranışı Envanteri isimli ölçek ile toplanmıştır. Ölçek Türkçeye araştırmacı tarafından uyarlanmıştır.
\end{abstract}

27 Araştırma, Ebru Korkmaz’ın Sa. Ü. Sosyal Bilimler Enstitüsü bünyesinde gerçekleştirdiği yüksek lisans tezinden yararlanılarak geliştirilmiştir.

* Sorumlu Yazar. Tel:+90 5326269724 E-posta: hgunduz@gmail.com

(C) 2011 Kalem Eğitim ve Sağlık Hizmetleri A.Ş. Bütün Hakları Saklıdır ISSN: 2146 - 5606 
Araştırma sonucuna göre; öğretmenler, ilköğretim okul yöneticilerinin dağıtımcı liderlik davranışlarını yüksek düzeyde gösterdiklerini düşünmektedirler. Benzer biçimde öğretmenler, ilköğretim okul yöneticilerinin model olma, etkileme, zorluklarla başa çıkma, imkân tanıma ve cesaretlendirme liderlik davranışlarını da gösterdiklerini ifade etmişlerdir. Öğretmenlerin büyük çoğunluğu okul müdürlerinin; birlikte çalıştığ 1 insanlar arasında iş birliğine dayalı ilişkiler geliştirdiğini; iyi iş yapmış birisini takdir ettiğini, farklı bakış açılarını aktif bir şekilde dinlediğini; diğer insanlara değer verdiğini ve kurumun ilerlemesi için kabul edilmiş ortak değerler sistemi içerisinde uzlaşma sağladığını belirtmiştir. İlköğretim okul yöneticilerinin dağıtımcı liderlik düzeyleri hakkındaki görüşlerinde öğretmenlerin cinsiyetine, yaş grubuna, bulunduğu okulda çalıştıkları süreye, okul yöneticisiyle birlikte çalıştıkları süreye, en son bitirdikleri okula ve branşlarına göre anlamlı bir fark olmadığı görülmüştür. Öte yandan okul yöneticilerinin okulda geçirdikleri zaman açısından gösterdikleri liderlik davranışlarının farklı olduğu bulunmuştur.

Anahtar kelimeler: Liderlik; Dağıtımcı liderlik; Yönetim; İlköğretim; Okul müdürleri.

\title{
Indiceting Levels of Distributive Leadership Behaviours of Primary School Principals
}

\begin{abstract}
The purpose of this study was to investigate the elementary school teachers' perceptions about the principals' practice for the distributed leadership. In the study, the general survey model was used to collect the quantitative data from the participants. Data were collected by a liker-type questionnaire developed by Kouzes ve Posner (2001) named as "Leadership Practices Inventory" (LPI). The results of the study indicated that the participants in this study reported that they have generally positive opinions about the principals' practice of distributed leadership. Most of the teachers think that the principals develop cooperative relationships among the people, praise people for a job well done, actively listen to diverse points of view, treats others with dignity and respect, and build consensus around a common set of values for running the
\end{abstract}


organization. According to the comparison there was not a statistically significant difference between the elementary school teachers' ideas about the principal's practice for the distributed leadership based on teachers' gender, educational status, educational status-other, age, the time that they worked in the school, major, and major-other. However, there was a statistically significant difference between the principals' time of the school.

Keywords: Leadership; Distributed leadership; Management; Primary education; School principals.

\section{Giriş}

Yeni yüzy1l, kaos, belirsizlik ve ivmesi baș döndüren bir değişim dünyası açmaktadır. Dahası, artan karmaşıklık ve bağımlılık anlamına gelen bu değişim, giderek doğrusal olmayan, süreksiz ve öngörülemeyen bir hâl almaktadır Yenilik, esneklik, yeni duruma hızlı tepki verme (fark etme ve uyum sağlama), fırsatların ve piyasaların yaratıcı bir şekilde yeniden tanımlanması, giderek daha birbirine bağlı (interconnected) küresel bir ekonomide rekabet avantajı kazanmanın yeni kaynakları olmaktadır.

Bu değişim, rekabetten çok iş birliğini (MacCormack ve Forbath, 2008), ürünün (sonucun) değerlendirilmesini öne çıkarmaktan çok, başarının sosyal ve çevresel performansı kapsayan çoklu ölçütlere göre değerlendirilmesini (Maltz, Shenhar ve Reilly, 2003), korku tabanlı yönetimden güven ortamı yaratma ve yetkilendirme tabanlı bir yönetimi öngören bir yönde gelişmektedir (Conger ve Kanungo, 1998; Chen, Kirkman, Kanfer, Allen, Rosen, 2007).

Bu bağlamda, örgütlerin yönetim düşüncesinin sürekli olarak arıtılmış yeni bilgiler ile güncellenmesi ve test edilmesi bir zorunluluk hâlini almıştır (Bennis, 1997; Covey, 1997). Bunu gerçekleştirebilmek için her örgütün yeni fırsatları keşfetmesi ve onların temel sayıltılarının değerlendirmesi gerekmektedir (Hammer, 1997). Bu kritik bilgiyi toplamak 
ve yorumlamak için kim sorumlu olacaktır? Çok önemli ve çok zor olan böyle bir işin, yetkilendirilmiş küçük bir azınlık tarafından başarılması oldukça güçtür. Örgütsel açıdan hayati önem taşıyan bu görev, en üst yönetimden en alt çalışana kadar herkesin işinin bir parçası olmalıdır (Dess, ve Picken, 2000). Bu zor görevin başarılması, içinde bulunulan dünyaya, örgüte ve onun yönetimine yeni bir bakışla gerçekleşen etkili liderliği gerektirmektedir. Bu soruna önerilen çözümlerden biri de dağıtımcı liderliktir.

Geçmişte benimsenen, rekabet ve hiyerarşiye dayalı liderlik modelleri, küresel karmaşıklık, hızlı değişim, karşılıklı bağımlılık gibi çok yönlü sorunlarla baş etmek için yeterli olamamaktadır (Clegg, Clarke ve Ibarra, 2001; Harman ve Hormann, 1990; Ray ve Rinzler, 1993; Wheatley, 1992). Bu nedenle yaklaşık yirmi yıldır, liderlik teorilerinde ve uygulamada bir değerler dizisi (paradigma) değişimi daha yoğun olarak tartış1lmaktadır (Harman, 1992; Clegg, Clarke, ve Ibarra, 2001; Spillane, Halverson ve Diamond 2004).

Liderlik, ilgi çekici ve oldukça tartışmalı bir olgu olmuştur. Liderlikle ilgili literatür incelendiğinde, binlerce araştırma ve yüzlerce tanım olduğu görülmektedir (Bass, 1985; Brestrich Topçu, 2000; Çetin, 2008; Erçetin, 2000; Şişman, 2002). Bu kadar çok tanım olmasını, Stogdill (1974) liderliğin; bireysel özelliklere, davranışa, diğer bireyler üzerindeki etkisine, etkileşim yapılarına, rol ilişkilerine, bir yönetim pozisyonundaki kullanım alanına ve etkiyi kabul edenlerin algılarına göre (Yukl, 2002) tanımlanmasından kaynaklandığını ifade etmektedir. Liderlik teorileri gelişim sırasına göre literatürde; özellikler teorileri, davranışçı teoriler ve durumsallık teorileri ve yeni teoriler olarak sinıflanmaktadır (Brestrich Topçu, 2000; Çelik, 1999; Erçetin, 2000; Hoy ve Miskel, 2010; Şişman, 2002). Yeni teoriler; etik liderlik, kültürel liderlik, öğretim liderliği (Çelik, 1999; Şişman, 2002), vizyoner liderlik (Bennis ve Nanus, 1985; Kouzes 
ve Posner, 1987), dönüşümcü ve sürdürümcü liderlik (Bass, 1985), kuantum liderlik (Erçetin, 2000; O’Grady ve Malloch, 2007), kendi kendine liderlik, dağıtımcı liderlik (Pearce ve Conger, 2003), dağıtılmış liderlik (Gronn, 2002) karizmatik liderlik (Conger ve Kanungo, 1987; House, 1977; Shamir, House ve Arthur, 1993), hizmetçi liderlik (Greenleaf, 1991; Spears, 2004) interaktif liderlik, otantik liderlik (Luthans ve Avolio, 2003), ruhsal liderlik (Fry, 2003), uyum sağlayıcı liderlik (Linsky ve Heifetz, 2002), çoğulcu liderlik (Kezar, 2000; akt. Özçimenli, Güleş ve Turan) karmaşık sistemlerde liderlik (Marion ve Uhl-Bien, 2001; Uhl-Bien, Mrion ve Mckelvey, 2007), İyiliksever Liderlik (Karakas, 2009), DNA liderlik (Ball, 1997; Gündüz, Beşoluk ve Önder, 2011) olarak sayılabilir.

Bu çalışmada yeni liderlik teorileriyle ilgili bir açıklama ya da değerlendirmeye girilmemiştir. Bunun yerine liderlik olgusu, yeni liderlik teorilerinden olan dağıtımcı liderlik yaklaşımı tartışıımıştır.

\section{Dağıtımcı Liderlik}

Bilim adamları okul yönetimi ve liderliği araştırmalarında çalışmalarını farklı kavramlaştırma ve yöntemsel yaklaşımlarla destekleyerek, giderek artan bir biçimde dağıtımcı perspektifi kullanmaktadırlar (Camburn, Rowan ve Taylor, 2003; Harris, 2005; MacBeath, Oduro ve Waterhouse, 2004; Spillane, Camburn ve Pareja, 2007; Spillane, Hunt ve Healey, 2009; Timperley, 2005). Bu bağlamda dağıtımcı perspektifin, okul liderliği ve yönetimi ile ilgili yeni bilgiler üretmek potansiyeline sahip olduğu söylenebilir (Gronn, 2000; Spillane, Halverson, ve Diamond, 2001, 2004).

Dağıtımcı liderlik terimi ilk defa Gibb (1954) "Liderlik" isimli kitabın birinci baskısında "Sosyal Psikolojinin Elkitabı" adlı bölümün yayımlanması ile bilim çevrelerinin dikkatini çekmiştir (Gronn, 2002). Gibb (1954) otokratik, babacan, bireysel ve katılımc1 olmak üzere dört liderlik çevresi olduğunu ifade etmiştir. Tanımladığı dört liderlik çev- 
resinden biri olan katılımcı çevreyi anlatırken Gibb (1954) büyüme ve grubun tüm üyelerinin gelişimine azami önem verildiğini ve liderin bir kişi olamayacağını; liderliğin paylaşılmış olduğunu ifade etmiştir.

Daha sonra güncel yazarların birçoğu, bu fikri kullanarak; liderlik işlevlerinin paylaşılmasına inanıldığı durumları betimlemek için, demokratik liderlik (Bass, 1990), öğretmen liderliği (Harris ve Muijs, 2005), konum-merkezli yönetim (Murphy ve Beck, 1995; Bauer ve Bogotch, 2001), dağıtılmış karar verme (Committee on Human Factors, 1990), dağıtılmış biliş (Hutchins, 1996), kolektif liderlik (Burns, 1998), paylaşılmış liderlik (Judge ve Ryman, 2001; Sergiovanni, 1995), serpilmiş liderlik (Bryman, 1996; Miller, 1998), dağıtıcı liderlik (Brown ve Gioia, 2002) ya da dağıtılan liderlik (Brown, 1989; Brown ve Hosking, 1986) gibi kavramları geliştirdiler. Bazı yazarlar da bu kavramı (Chityayat, 1985; Denis, Lamothe ve Langley, 2001; Gronn, 1999; Heenan ve Bennis, 1999; Stewart, 1991; Yuk1, 1999), ikili liderlik, ikili kontrol, toplu liderlik, eş-liderlik ya da liderlik çifti olarak adlandırarak tartıştılar. $\mathrm{Bu}$ araştırmada ise kavram, dağıtımcı liderlik olarak kullanılmaktadır.

Araştırmacılar, yukarıda ifade edilen kavramlarla, kahraman liderlik paradigmasının bir eleştirisi olan dağıtımcı liderlik kavramının; holografik bir yaklaşımla liderlik işlevlerinin bir kişi yerine, bir grup insanın topluca yerine getirmesine dikkat çekmektedirler. Bazı liderlik rollerinin bir grubun birkaç üyesi tarafından paylaşılabileceğini, bazı liderlik işlevlerine üyelerden birilerinin atanabileceğini, belirli liderlik işlevlerinin farklı zamanlarda farklı bireylerce yerine getirebileceği ifade edilmektedir. Bu anlayışa göre, örgüt üyeleri tarafından sağlanan kolektif liderlik eylemleri, herhangi birinin bireysel liderliğine tercih edilmektedir (Gron, 2002; Yuk1, 1999 ).

Araştırmacılar arasında liderliğin tanımlanmasında olduğu gibi algılanmasında da görüş ayrılıkları bulunmaktadır. Liderlik, bir süreç, 
bir rol veya bir söylem olarak düşünülebilmektedir (Grint, 2005; Parry ve Hansen, 2007). Örneğin Spillane (2006) dağıtımcı liderliği liderliğin sınanmasını sağlayan bir yapı olarak görürken, Bennett, Harvey, Wise ve Woods (2003) ise dağıtımcı liderliğin "düşünme yolları" olarak düşünülebileceğini önermektedir. Chen (2007)'e göre ise dağıtımcı liderlik değişik liderlik uygulamalarının bir gelişim süreci olarak görülmektedir.

Yazarların liderliği algılayış biçimleri, liderliğe yaklaşımlarını ve bunun sonucu olarak tanımlarını da değiştirmektedir. En geniş perspektiften liderliğin algılanması, geçmişin, şimdinin ve geleceğin anlamlandırılmasıdır; amacın algılanması ki bu, sayıltıların değerlerle bağlantısını kurma ve eylem için hedefleri sıraya koymadır (Pye, 2005).

Uygulamaya dönük bir davranış olarak algılama, problem çözme ve yaratıcı yenilikçi çözüm üretmeye odaklanmaktır. Bu bakımdan faaliyette bulunan çok daha fazla insan arasında liderliğin dağıtılmış olması, liderin tek başına eylemde bulunmasından daha iyidir (Kempster, Cope ve Parry, 2010).

Liderlik, örgütün diğer üyelerinin bilgi, güdüleme, arzu ve uygulamalarını etkilemek için örgütün diğer üyelerince tasarlanmış veya örgüt üyelerinin duygularını, bilgilerini, güdülenmelerini ve faaliyetlerini etkilemek olarak anlaşılan, örgütün çekirdek işine bağlı faaliyetlere işaret etmektedir (Spillane, 2003).

Güçlü tek lider anlayışına alternatif olabilecek yeni liderlik anlayışını, Yukl (1989) örgütün ya da grubun hedeflerinin belirlenmesini içeren süreçleri etkileme, bu hedeflerin sürdürülmesinde görev davranış1 güdüleme ve örgütün sürekliliğini ve kültürünü etkileme olarak tanımlamakta ve liderliği, işlerin verimli yürümesini sağlamak amacıyla, insanların bireysel ve müşterek kapasitelerini artıran dağıtımcı bir süreç olarak görmektedir. 
Dağıtımcı liderlik, gücün yeniden dağıtılması ve yetkilerin yeniden düzenlenmesi (Harris ve Muijs, 2005) olarak da tanımlanmaktadır. Dağıtımcı liderlik, bir okuldaki tüm liderlerin ve onların daha geniş ölçekli bir liderlik davranışına ulaşmak için çabalarının toplamından daha fazla bir etkiye sahiptir (Spillane, 2006).

House ve Aditja (1997)'da dağıtımcı liderlik sürecinin sadece bir bireyin davranışları açısından tanımlanamayacağını; daha ziyade liderliğin olumlu değişikliğin etkinleşmesi için birlikte çalışan insanların paylaşılan değerlerine dayalı müşterek bir davranışa yol açan iş birliği ilişkilerini içerdiğini ifade etmişlerdir.

Kendi kendini yöneten takımlarda dağıtımcı liderlik araştırmasında Barry (1991) "liderliği, parçalara bölünebilir, paylaşılan, dönüşümlü ve sıralı veya eş zamanlı olarak kullanılan, roller ve davranışlar bütünü” olarak tanımlamıştır. Her bir liderin birbirini tamamlayıcı bir rolü olduğu varsayımı ile, herhangi bir zamanda bir takımda birden fazla lider olabileceği görüşündedir.

Barret (1998)'a göre ise liderlik rolü, bir grupta bir bireye tayin edilmiş bir görev değildir, grubun tüm bireyleri bu işlevi asli görevleriymiş gibi kendiliğinden üstlenerek yerine getirmektedir (Storey, 2004). Ona göre liderlik duygusal bağlarla güçlenen bireyler için kişisel birer sorumluluktur. Bu konuyla bağlantılı diğer kavramlar arasında "kendi kendini yönetebilme, kendiliğinden gelişen grup çalışma birlikleri, güçlenme, demokrasi” sayılabilir. Bazı kesimlerce de şöyle bir şüphe vardır: Liderlik, bu sayılan ve öncesinde de bilinen, varlığını sürdüren tanımların birleştirilip yeni bir isim verilmiş, etiketlenmiş hâlidir. Fakat dağıtımcı liderlik bu düşüncenin çok daha ötesinde amaçlar barındıran farklı bir değerdir. Dağıtımcı liderliğin, kendi anlam ve değeri bu süreçte yeni yeni keşfedilmeye başlanmaktadır (Storey, 2004).

Dağıtımcı liderlik, "dağıtımcı karar verme" gibi kavramlara çatı- 
l1k etmekle beraber 21. yüzyıldaki tanımlarda daha geniş kapsamlıdır. Dağıtımcı liderliğin tanımında bir uzlaşmaya varılamamış da olsa, genel olarak 'meslektaşlar arası etkileşim ve iş birliği'ne yakın anlamlar yüklenmiştir. Liderliğin, okul topluluğunu oluşturan yöneticiler, öğretmenler, diğer çalışanlar ve okulla ilişkili olan diğer bireylere paylaştırılmış olan fonksiyon ve nitelikler olduğunu göz önüne alınırsa, dağıtımcı liderliğin, günümüz liderlik anlayışına yön verebileceği görülmektedir. Liderliğin tanımı ile ilgili bu yaklaşım, okulun ve/veya okul sisteminin dağıtımcı liderlik sistemlerine ve süreçlerine ne kadar ihtiyacının olduğunu da göstermektedir (Chen, 2007, s.17).

Yeni literatürdeki tanımlardaki bazı çeşitliliklere rağmen dağ1tımcı liderlik üç tema üzerine yapılandırılmıştır: Birincisi, liderliğin bir grubun ortak ürünü ve bireylerin etkileşimi sonucu şekillendiği; ikincisi liderlikte sınırların kesin ve net hatlarla çizilmemesi yani açık olması; üçüncüsü ise uygulamadaki bu çeşitliliklerin üyelerin bir kısmı hatta tamamı ile birlikte sağlanmasıdır. Böylece, dağıtımcı liderlik; dinamik, değişen, ilişkisel, bütüncül içeriği oluşturulmuş bir yapı olarak temsil edilmektedir (Bolden vd., 2009).

Yine de bu tanımların hiçbiri, dağıtımcı liderliğin bir örgütte nasıl tanımlanacağını göstermez. Bu gereği karşılamak üzere çeşitli girişimler olmuştur. Dağıtımcı liderliğin uygulanmasına yönelik sınıflamalardan biri House ve Aditja (1997)'ya aittir. Onlara göre dağıtımcı liderlik, yetki devrine dayalı liderlik (delegated leadership), eşliderlik ve akran liderlik olmak üzere üçlü olarak sıralanabilir. Fakat House ve Aditja (1997) aynı zamanda bu üç liderlik biçiminin anlaşılmasının zor olduğunu ve bu görüşlerini destekleyecek görgül verilerin de yetersiz olduğunu kabul etmektedirler.

Liderlik dağıtıldığında liderlik uygulamalarının nasıl ilişkilendirileceğini anlamak için, Spillane (2003) Goldstein'in dağıtımcı liderliğin 
liderlik görevlerinin yerine getirilmesinde, bölünmüşs sorumluluk ve dağıtılmış sorumluluk olmak üzere iki model önerdiğini ifade etmektedir.

Gronn (2002) yaptığı meta analize dayalı olarak, dağıtımcı liderliği, uyumlu ve sayısal davranış olmak üzere iki boyutlu olarak sınıflandırmıştır. Uyumlu davranış, etkileşimde bulunan farklı birimlerin/ bölümlerin üyelerinin birbirlerinin davranışını gözeterek eş güdümlü davranmaları olarak görülürken, sayısal davranış, örgütteki bütün bireylerin bir zaman lider olabileceğini ileri sürer. Gronn (2002) uyumlu davranışın, ya kendiliğinden ya inisiyatif alınarak ya da kurumsallaşma ile olabileceğini düşünmektedir.

Spillane, Diamond ve Jita (2003), dağıtımcı liderliğin iş birlikçi, toplu ve eş güdümlü dağıtım olmak üzere üç biçimde uygulanabileceğini önermektedir. İş birlikçi paylaşım, bir liderin uygulamasının diğeri için temel oluşturduğu, liderlerin belirli bir liderlik işlevini yerine getirmek için birlikte çalıştığı liderlik uygulamasıdır. Toplu paylaşım, tek başına çalışan fakat genel bir uygulamayı üreten birbirine bağlı davranışları kapsayan paylaşılan bir amacın yerine getirilmesinde birbirine bağlı çalışan iki veya daha fazla liderin uygulamalarına işaret eder. Eş güdümlü liderlik, farklı liderlik görevlerinin, bazı liderlik işlevlerinin eş güdümlü yürütülebilmesi için belirli sırada yerine getirilmesi zorunluluğunu ifade eder. Bu görevlerin yerine getirilebilmesi için liderlerin sorumlulukları ve görevleri arasındaki bağımlılık sıralıdır (Spillane, 2003; Spillane, Diamond ve Jita, 2003).

Dağıtımcı liderlik kuramında Spillane (2006), lider-artı yön ve pratik yön olmak üzere dağıtımcı bakış açısının iki yön içerdiğini ifade ederek dağıtımcı liderliği iki boyutlu olarak sınıflamıştır. Lider-artı yön, okulları yönlendirme ve yönetmede, okul müdürüne ek olarak liderlik veya yöneticilik makamına resmen atanmış, müdür yardımcıları, rehber öğretmenler ve program geliştirme uzmanları gibi birden çok kişinin rol 
alabileceğini kabul eder.

Resmen atanmış diğer liderler okulu yönlendirme ve yönetmede kritik bir rol oynadıkları için, mevcut ampirik çalışma, okul müdürünün bir anlamda sınırlandırıldığını göstermektedir (Camburn et al., 2003; Harris, 2005; Leithwood, Mascall, Strauss, Sacks, Memon ve Yashkina, 2007; MacBeath vd. 2004; Spillane ve Diamond, 2007). Uygulama açısından dağıtımcı perspektif, herhangi bir formal liderlik rolü olmaksızın bireylerin okul yönetiminde sorumluluk alabilme olasılığına izin verir. Bazı tasvirlerin aksine, dağıtımcı perspektif herkesin yönetme ve yönlendirme işi içinde olması da gerekmez (Spillane, 2006; Spillane ve Diamond, 2007; Spillane ve Healey, 2010). Açıkça alakalı olmasına rağmen dağıtımcı perspektiften uygulama, sadece bireysel liderlerin eylemlerinden ibaret değildir, bundan çok temel olarak etkileşimleriyle iliş̧kilidir (Spillane, 2006).

Dağıtımcı bakış açısından uygulama, liderler ve izleyenler arasındaki etkileşimin ve onların içinde bulundukları durumun bir ürünü olarak alt yapıyı oluşturduğu için, eylemler, yetersiz kalmaktadır. Bu çerçeve içinde, okul personeli (müdürü, program geliştirme uzmanı, ya da sınıf öğretmeni olabilirler) aktivite veya duruma göre liderlik ve yönetim rolleri içinde veya dışında hareket edebilirler. Şüphesiz, formal olarak atanmış liderler örneğin okul müdürü, daima kendilerine verilmiş olan statüye sahiptir. Bu nedenle, dağıtımcı perspektiften liderlik ve yönetimin altyapısını, okul örgütünün formal ve informal yönünün yanı sıra, formal ve informal yönleri arasındaki ilişkiler de ön plana çıkar (Spillane ve Healey, 2010).

Bu yeni bakış açısı, liderin rolünün, özelliklerinin, yeteneğinin ve bilişinin bir araştırması olmaktan ziyade, yönünü liderliğin uygulanmasına çevirmiştir. Bu yeni bakış açısı ile Spillane (2006) liderliği okul aktörlerinin iletişimlerinin etkileşimli bir ürünü olarak eserleri ve 
durumu kullanmaları olarak tanımlamaktadır.

Okul personelinin etkileşimleri, Spillane’’n dağıtılmış liderliğin uygulanmasına dayalı teorisinin sadece bir bileşenidir. Eğitimcilerin yararlandığı çeşitli somut eserler veya toplantı gündemi, program rehberleri, değerlendirme veri veya gözlem formları gibi öğretim araçları bu teorinin ayrılmaz bir parçasıdır. Soyut kültürel ilkeler de, okul vizyonu, hedefleri ve beklentileri içeren eserler de kavramın içindedir. Durum kavramı, günlük yaşantı ve okul çalışanları tarafından tamamlanmış görevleri ifade eder (Davis, 2009).

Dağıtımcı liderliğin güncel teorik tartışmaları coğrafi alan temelinde sınıflandığında; İngiltere, Kuzey Amerika ve Avustralya ağırl1k kazanmakta (Glen, 2009) ve bu alanlarda da James Spillane, Peter Gronn ve Richard Elmore isimleri öne çıkmaktadır (Harris, 2005). Bu nedenle dağıtımcı liderliğin tanımlanmasında bu üç yazarın tanımları ağırlık kazanmıştır. Spillane, Gronn ve Elmore'un dağıtımcı liderlik tanımları incelendiğinde, dağıtımcı liderlik, öğretimi iyileşme sürecinde öğretmenleri yönlendiren, rehberlik yapan, birlikte çalışan bireylerin ilişkiler ağının sonucunda ortaya çıkan uzmanlık, bilgi ve katkılarına dayandırılmaktadır (Davis, 2009).

Elmore (2000) okul sistemlerinde öğrenmeye ve öğretimi geliştirmeye odaklı dağıtımcı liderlik için bazı ilkeler de önermiştir. Bunlardan ilki liderliğin amacı, uygulama ve performansı artırmaktır. İkincisi, gelişme, bireyler ve grupların ve her ikisinin birlikte, sürekli öğrenmesini gerektirir. Öğrenmeyi herkesin menfaatine uygun, "ortak iyi” olarak gören bir ortam oluşturma dağıtımcı liderlik için çok önemlidir. Üçüncü olarak, liderler, başkalarına kabul etmesini istedikleri değerleri ve davranışları yönlendirmek için, kendileri model olurlar. Öğrenme dağıtımcı liderliğin temelinde yer aldığ 1 için, liderler başkalarının meşgul olmasını beklediği öğrenme için kendileri model olmalıdır. Dağıtımcı liderlik modeli 
sınıfta olan şeyleri, hem bireysel ilgi hem de toplu iyi olarak kabul eder (Elmore, 2000). Dağıtımcı liderlik, farklı uzmanlıklara saygı göstererek, onları kabul ederek ve etkileşimlerden doğan bilgi dâhil her türlü ürünü örgütün ortak sermayesi hâline getirerek, örgütte oluşturulan öğretimsel gelişmede tutkal görevi görür.

Chen (2007), dağıtımcı liderliğin beş ayırt edici özelliğe sahip olduğunu belirtmiştir. Bunlar; müşterek liderliğin bir formu olarak dağıtımcı liderlik, öğrenci başarısına ve öğretimde gelişmeye yönelme, diğer insanların yeteneklerinin farkına varabilme, sınırların aşılması ve liderler, takip edenler ile onların içinde bulundukları durum arasındaki etkileşime odaklanmadır.

Dağıtımcı liderliğin üç tema üzerine yapılandırıldığı söylenebilir. Birincisi, liderliğin bir grubun ortak ürünü ve bireylerin etkileşimi sonucu şekillendiği; ikincisi liderlikte sınırların kesin ve net hatlarla çizilmemesi yani açık olması; üçüncüsü ise uygulamadaki bu çeşitliliklerin üyelerin bir kısmı, hatta tamamı ile birlikte sağlanmasıdır. Böylece, dağıtımcı liderlik; dinamik, değişen, ilişkisel, bütüncül içeriği oluşturulmuş bir yap1 olarak temsil edilmektedir (Bolden vd., 2009).

Dağıtımcı liderlikte iki önemli özellik bulunmaktadır. Gronn (2002)'a göre bu iki özellik; dayanışma ve uyumluluktur:

- Dayanışma: Bilgi ve desteğin kaçınılmaz ve karşılıklı ihtiyacıdır. İki ana yolla işlev görür. Birincisi, üyelerin sorumlulukları kesişebilir. İkincisi ise, üyelerin sorumlulukları birbirini tamamlayabilir. Her iki durumda da dayanışma vazgeçilemeyecek bir unsurdur ve doğal bir ihtiyaç olarak ortaya çıkmaktadır. Dağıtımcı liderlik, bu doğal ihtiyacı karşılamaktadır.

- Uyumluluk: Aktiviteler arasındaki bağımlılıkları yönetme olarak görülebilir. Uyumluluk ayarlamaları personel, kaynak, materyal, görev, ürün ve yörüngeyi kapsar. Zamanlama, planlama, 
standart hâle getirme (kalite kontrol, kaynakların bölüşümü gibi), bilgi yönetimi, iletişim, müzakere etme, teklif verme ve siralama uyumluluk mekanizmalarıdır.

- Dağıtımcı liderliğin bir diğer önemli özelliği ise resmî ve gayri resmî liderler arasında liderliğin nasıl dağıtıldığıdır. Dağıtımcı liderlikte liderlik paylaşımı demek, bir bireyin bir işi diğerlerine karşı nasıl yaptığı değildir. Liderlik paylaşımı demek, liderlik grubunda olan kişilerin bir grup olarak bilgi havuzuna ne kattığıdır (Gronn, 2002).

Bu özelliklere ek olarak, dağıtımcı liderlik kuramları ve tanımları incelendiğinde yukarıda verilen özelliklere bazı eklemeler yapılabilir. Bunlar (Chen, 2007); müşterek liderliğin bir formu olarak dağıtımcı liderlik, öğrenci başarısına ve öğretimde gelişmeye yönelme, diğer insanların yeteneklerinin farkına varabilme, sınırların aşılması ve liderler, takip edenler ve onların içinde bulundukları durum arasındaki etkileşime odaklanma olarak sayılabilir.

Okulun birey boyutu kurum boyutundan daha duyarlı, informal yanı formal yanından daha ağır, etki alanı yetki alanından daha geniş açık sosyal bir sistem (Bursalığlu, 2008) olmasından hareketle dağıtımcı liderliğin, okullarda daha kolay uygulama alanı bulabileceği yaygın bir kanaat olarak kabul görmektedir (Spillane, Camburn, ve Pareja, 2007; Spillane, Hunt ve Healey, 2009). Hulpia, Devos ve Rosseel (2009)'a göre, dağıtımcı liderler, okul sisteminde dönüşümsel ve pozitif değişim için potansiyel katkıda bulunan kimselerdir. Bilgi toplumunun getirdiği hızlı değişim ve dönüşüme uyarlanabilme diğer alanlar kadar eğitim örgütlerini zorlamaktadır. Bu yüzyılda örgütler daha karmaşık bir hâl almaktadırlar. Okul sistemleri yeni ve ihtiyaçlarına cevap vermeye daha hazır liderlik bakış açılarına ihtiyaç duymaktadır. Bu hızlı değişimle başa çıkabilmede eğitim yöneticileri ve liderlerinin dağıtımcı liderliğin perspektifinden 
bakabilmelerinin onlara önemli avantaj sağlayacağı düşünülmektedir. Bu bağlamda araştırmanın amacı, öğretmen görüşlerine göre ilköğretim okulu yöneticilerinin dağıtımcı liderlik davranışlarını gösterme düzeylerini belirlemektir.

$\mathrm{Bu}$ amaç doğrultusunda aşağıdaki sorulara cevap aranmıştır:

İlköğretim okullarında çalışan öğretmenlerin görüşlerine göre yöneticilerinin dağıtımcı liderlik davranışlarını gösterme düzeyleri nedir?

1. İlköğretim okullarında çalışan yöneticilerinin, öğretmenlerinin görüşlerine göre;

a. Model olma

b. Etkileme

c. Zorluklarla başa çıkma

d. İmkân tanıma

e. Cesaretlendirme

liderlik davranışlarını gösterme düzeyleri nedir?

Üzerinde araştırmalar, tartışmalar yapılan güncel bir liderlik perspektifi olarak dağıtımcı liderlikle ilgili araştırmaların okullarda yoğunlaşmış olması, okul yönetimleri ve yöneticilerinin geliştirilmesine önemli katkılar getirebileceği ümit edilmektedir. Dünyada birçok ülkede dikkatleri üzerine çeken bir perspektif olmasına karşın, Türk literatüründe dağıtımcı liderlikle ilgili araştırmalara rastlanılamamıştır. Bu araştırma ile dağıtımcı liderlikle ilgili kuram ve kavramların tanıtılması, Kocaeli ölçeğinde ilköğretim okulu yöneticilerinin dağıtımcı liderlik davranışlarının betimlenmesi yanında, eğitim yöneticilerinin dikkatlerinin konuya çekilmesi ve izleyen araştırmaları çağrıştırmada önemli katkılar yapacağı ümit edilmektedir. 


\section{Yöntem}

Araştırma tarama modelindedir. Araştırmada Kocaeli ilinde bulunan, Millî Eğitim Bakanlığına bağl1 ilköğretim okullarında çalışan yöneticilerin, dağıtımcı liderlik özellikleri öğretmen görüşlerine göre belirlenmeye çalışılmıştır. Araştırmanın katılımcılarını İzmit ilçesindeki 46 ilköğretim okulunda 2009 - 2010 öğretim yılında görev yapan uygun örnekleme yöntemi ile seçilen 300 öğretmen oluşturmuştur.

\section{Verilerin Toplanması}

Araştırmanın verilerinin toplanmasında Kouzes ve Posner (2001) tarafından geliştirilmiş olan “Liderlik Davranışı Envanteri” isimli ölçek kullanılmıştır.

Orjinali İngilizce olan ölçek, Korkmaz (2010) tarafından Türkiye’ye uyarlanmıştır. Ölçek Türkçeye uyarlanırken alanında uzman dört çevirmen tarafından İngilizceden Türkçeye çevrilmiştir. Bu çeviriler, başka bir uzman tarafından karşılaştırılarak tek bir form üzerinde toplanmıştır. Bu form, daha önce İngilizcesini hiç okumamış bir uzman tarafından Türkçeden İngilizceye çevrilmiştir. Son olarak, ölçeğin Türkçesi ile İngilizcesi karşılaştırılarak gerekli düzenlemeler yapılmış ve uzman görüşü alınarak ölçeğe son şekli verilmiştir.

"Liderlik Davranışı Envanteri” "model olma", "etkileme", “zorluklarla başa çıkma", "imkân tanıma" ve "cesaretlendirme" olmak üzere beş boyuttan oluşmaktadır. Ölçeğin boyutlarından ilki olan model olma, örnek oluşturma ve kişisel değerleri açığa kavuşturmayı, etkileme, gelecekte olabilecek şeyleri önceden tespit ederek, insanların gözleri önüne serme ve böylece herkesi bir amaç doğrultusunda buluşturabilmeyi, zorluklarla başa çıkma, risk alma, hatalardan öğrenme, büyümeye çalışma davranışlarını, imkân tanıma, güvenmeyi ve birlikteliği arayarak, ortak amaçlar taşıyan ve gücü paylaşan enerjik ve kazanan takımlar oluşturma davranışını ve cesaretlendirme ise başarıyı kutlayarak, takipçilerini 
yüreklendirme davranışlarını içermektedir (Korkmaz, 2010; Kouzes ve Posner, 2001). Ölçeğin her boyutundaki davranışlar 6 maddelik sorularla ölçülmektedir.

Ölçeğin, bu araştırmadaki geçerliliğinin sınanması için, araştırmacı tarafından doğrulayıcı faktör analizi (CFA) uygulanmıştır. CFA için AMOS 16.0 analiz programı kullanılmıştır. CFA sonuçlarına göre, bu beş boyutun modelle uyumlu olduğu bulunmuştur $\left(\mathrm{x}^{2}=912.2, \mathrm{df}=395\right.$, $\mathrm{p}=.000, \mathrm{RMSEA}=.066$ ).

Sonuçların güvenirliğini hesaplamak için ölçek çalışma grubu içinde yer almayan 150 kişiye uygulanmıştır. Verilen cevaplar doğrultusunda Cronbach Alpha güvenirlik katsayısı 0.96 bulunmuştur. Cronbach Alpha güvenirlik katsayısı model olma alt boyutu için 0.88, etkileme için 0.92 , zorluklarla başa çıkma için 0.89 , imkân tanıma için 0.88 ve cesaretlendirme alt boyutu için 0.92 olarak bulunmuştur. Araştırmanın gerçekleştirilmesi için gerekli olan izin Kocaeli İl Millî Eğitim Müdürlüğü’nden alınmıştır.

Ölçeğin uygulanmasından elde edilen veriler SPSS 16 programıyla çözümlenmiştir. Verilerin çözümlenmesinde aritmetik ortalama, frekans, yüzde ve standart sapma kullanılmıştır.

\section{Bulgular}

Araştırmanın bulguları alt amaçlardaki sıra dikkate alınarak sunulmuştur. Buna göre ilk başlık altında öğretmen görüşlerine göre yöneticilerin Liderlik Davranışı Envanteri'nin tümüne verdikleri cevaplardan hesaplanan puanlara dayalı olarak dağıtımcı liderliği gösterme düzeylerine ilişkin öğretmen görüşleri sunulmuştur. Daha sonra dağıtımcı liderliğin alt boyutlarını ne düzeyde gösterdiklerine ilişkin öğretmen görüşleri sunulmuştur. 


\section{Yöneticilerinin Dağıtımcı Liderlik Davranışlarını Gösterme Dü- zeyleri}

$\mathrm{Bu}$ başlık altında öğretmenlerin müdürlerinin dağıtımcı liderlik davranışlarını gösterme düzeylerine ilişkin bulgular, Tablo 1'de sunulmuştur.

Tablo 1. İlköğretim okullarında çalışan öğretmenlerin görüşlerine göre yöneticilerinin dağıtımcı liderlik davranışlarını gösterme düzeyleri.

\begin{tabular}{|l|c|c|}
\hline & Frekans & Yüzde \\
\hline Kesinlikle katıliyorum & 80 & 26.7 \\
\hline Kat1liyorum & 148 & 49.3 \\
\hline Fikrim yok & 37 & 12.3 \\
\hline Katılmiyorum & 15 & 5.0 \\
\hline Kesinlikle katılmiyorum & 5 & 1.7 \\
\hline Toplam & $\mathbf{2 8 5}$ & $\mathbf{9 5 . 0}$ \\
\hline
\end{tabular}

Tablo 1'e göre ilköğretim okullarında çalışan öğretmenlerin yaklaşık dörtte biri (\% 26.7) kesinlikle katılıyorum düzeyinde ve yarısına yakını (\% 49.3) katılıyorum düzeyinde yöneticilerinin dağıtımcı liderlik davranışlarını gösterdiklerini ifade etmişlerdir. Buna göre ilköğretim okullarında çalışan öğretmenlerin büyük bir çoğunluğunun (\% 76) yöneticilerinin dağıtımcı liderlik davranışlarını gösterdiklerini düşündüğü söylenebilir.

\section{Yöneticilerin Dağıtımcı Liderlik Davranışının Alt Boyutlarını Gös- terme Düzeyleri}

Bu başlık altında okul müdürlerinin dağıtımcı liderliği oluşturan, model olma, etkileme, zorluklara başa çıkma, imkân tanıma ve cesaretlendirme boyutlarını ne düzeyde gösterdiğine ilişkin öğretmen görüşleri sunulmuştur. 
Tablo 2. İlköğretim okulu yöneticilerinin dağıtımcı liderlik model olma davranışlarına ilişkin öğretmen görüşleri.

\begin{tabular}{|l|c|c|}
\hline & Frekans & Yüzde \\
\hline Kesinlikle kat1liyorum & 121 & 40.3 \\
\hline Kat1liyorum & 107 & 35.7 \\
\hline Fikrim yok & 50 & 16.7 \\
\hline Katılmiyorum & 12 & 4.0 \\
\hline Kesinlikle kat1lmiyorum & 6 & 2.0 \\
\hline Toplam & $\mathbf{2 9 6}$ & $\mathbf{9 8 . 7}$ \\
\hline
\end{tabular}

Tablo 2'ye göre ilköğretim okulu yöneticilerinin "model olma liderlik davranışını" öğretmenlerin yarısına yakını (\% 40.3) kesinlikle katılıyorum düzeyinde ve üçte birinden fazlası (\% 35.7) katılıyorum düzeyinde gösterdiğini belirtmiştir. Buna göre ilköğretim okulu öğretmenlerinin büyük çoğunluğu (\% 76) yöneticilerinin dağıtımcı liderlik davranışının model olma boyutunu kesinlikle katılıyorum ve katılıyorum düzeyinde gösterdiğini düşündükleri söylenebilir. Öğretmenlerin mesleki gelişiminde ve buna bağlı olarak örgütsel öğrenme ve okulun etkinliğini artırılmasında okul yöneticilerinin birer öğretim lideri olması beklenmektedir (Şişman, 2004; Erçetin, 2000; Gündüz ve Sezik, 2005). Okul yöneticisi verdiği sözlerin ve aldığı yükümlülüklerin arkasında durur. Kurumun ilerlemesi için kabul edilmiş ortak değerler sistemi içerisinde uzlaşma sağlar.

Tablo 3. İlköğretim okullarında çalışan yöneticilerin dağıtımcı liderlik davranışının etkileme alt boyutuna ilişkin öğretmen görüşleri.

\begin{tabular}{|l|c|c|}
\hline & Frekans & Yüzde \\
\hline Kesinlikle kat1liyorum & 86 & 28.7 \\
\hline Kat1liyorum & 115 & 38.3 \\
\hline Fikrim yok & 66 & 22.0 \\
\hline Katılmiyorum & 23 & 7.7 \\
\hline Kesinlikle katılmiyorum & 6 & 2.0 \\
\hline Toplam & $\mathbf{2 9 6}$ & $\mathbf{9 8 . 7}$ \\
\hline
\end{tabular}


Tablo 3'e göre ilköğretim okullarında çalışan öğretmenlerin yaklaşık dörtte biri (\% 28.7) kesinlikle katılıyorum düzeyinde ve üçte birinden fazlası (\% 38.3) katılıyorum düzeyinde yöneticilerinin dağıtımcı liderlik davranışının "etkileme” alt boyutunu gösterdiklerini belirtmiştir. Buna göre ilköğretim okullarında çalışan öğretmenlerin çoğu tarafından (\% 67) ilköğretim okul yöneticilerinin "etkileme liderlik davranışlarını" gösterdiklerini düşündükleri söylenebilir. Bu bulgu Chen (2007)'in ABD yaptığı araştırmanın bulguları ile paralellik göstermektedir. Örneklem farklılığına karşın yöneticilerin dağıtımcı liderlik anlayışının öğretmenlerce olumlu karşılandığı görülmektedir. Bu bulguya dayanarak ilköğretim okul yöneticilerinin öğretmenlerin vizyonuna renk kattıkları ve öğretmenleri bir amaç doğrultusunda buluşturdukları söylenebilir.

Tablo 4. İlköğretim okullarında çalışan yöneticilerin dağıtımcı liderlik davranışının zorluklara başa çıkma alt boyutuna ilişkin öğretmen görüşleri.

\begin{tabular}{|l|c|c|}
\hline & Frekans & Yüzde \\
\hline Kesinlikle katıliyorum & 68 & 22.7 \\
\hline Kat1liyorum & 121 & 40.3 \\
\hline Fikrim yok & 82 & 27.3 \\
\hline Kat1lmiyorum & 21 & 7.0 \\
\hline Kesinlikle katılmiyorum & 5 & 1.7 \\
\hline Toplam & $\mathbf{2 9 7}$ & $\mathbf{9 9 . 0}$ \\
\hline
\end{tabular}

Tablo 4'e göre ilköğretim okulu yöneticilerinin “'zorluklarla başa çıkma liderlik davranışını” öğretmenlerin yaklaşık dörtte biri (\% 22.7) kesinlikle katılıyorum düzeyinde ve yarısına yakını (\% 40.3) katılıyorum düzeyinde gösterdikleri görülmektedir. Buna göre ilköğretim okulu öğretmenlerinin çoğunluğu (\% 63) tarafından yöneticilerinin dağıtımcı liderlik davranışının zorluklarla başa çıkma boyutunu kesinlikle katılıyorum ve katılıyorum düzeyinde gösterdiğini düşündükleri söylenebilir. 
Buna göre okul yöneticilerinin risk aldıkları; var olan durumu değiştirmek için fırsat aradıkları; çalışma ortam ve koşullarını geliştirmek için farklı yollar denemeye çalıştıkları söylenebilir.

Tablo 5. İlköğretim okullarında çalışan yöneticilerin dağıtımcı liderlik davranışının imkân tanıma alt boyutuna ilişskin öğretmen görüşleri.

\begin{tabular}{|l|c|c|}
\hline & Frekans & Yüzde \\
\hline Kesinlikle katıliyorum & 140 & 46.7 \\
\hline Kat1liyorum & 98 & 32.7 \\
\hline Fikrim yok & 36 & 12.0 \\
\hline Kat1lmiyorum & 20 & 6.7 \\
\hline Kesinlikle katılmıyorum & 3 & 1.0 \\
\hline Toplam & $\mathbf{2 9 7}$ & $\mathbf{9 9 . 0}$ \\
\hline
\end{tabular}

Tablo 5'e göre ilköğretim okulu yöneticilerinin “imkân tanıma liderlik davranışını” öğretmenlerin yarısına yakını (\% 46.7) kesinlikle katıl1yorum düzeyinde ve yaklaşı1k üçte birinin (\% 32.7) katılıyorum düzeyinde gösterdiğini belirtmiştir. Buna göre ilköğretim okulu öğretmenlerinin büyük çoğunluğu (\% 89.4) tarafından yöneticilerin dağıtımcı liderlik davranışının imkân tanıma boyutunu "kesinlikle katılıyorum" ve "katılıyorum" düzeyinde gösterdiğini düşündükleri söylenebilir. Buna göre ilköğretim okullarında iş birliğine dayalı ilişkiler olduğu ve öğretmenlere işlerini nasıl yapacakları konusunda kayda değer bir özgürlük ve seçme şansı verildiği düşünülebilir. Öğretmenlerin, okul yöneticilerinin farklı bakış açılarını aktif bir şekilde dinlediği, diğerlerine değer verip saygılı davrandıklarını düşündükleri söylenebilir. 
Tablo 6. İlköğretim okullarında çalışan yöneticilerin dağıtımcı liderlik davranışının cesaretlendirme alt boyutuna ilişkin öğretmen görüşleri.

\begin{tabular}{|l|c|c|}
\hline & Frekans & Yüzde \\
\hline Kesinlikle kat1liyorum & 127 & 42.3 \\
\hline Kat1liyorum & 103 & 34.3 \\
\hline Fikrim yok & 41 & 13.7 \\
\hline Katılmiyorum & 17 & 5.7 \\
\hline Kesinlikle katılmiyorum & 7 & 2.3 \\
\hline Toplam & $\mathbf{2 9 5}$ & $\mathbf{9 8 . 3}$ \\
\hline
\end{tabular}

Tablo 6'ya göre ilköğretim okullarında çalışan öğretmenlerin yarısına yakını (\% 42.3) kesinlikle katılıyorum düzeyinde ve üçte birinden fazlasının (\% 34.3) katılıyorum düzeyinde yöneticilerinin "cesaretlendirme liderlik davranışlarını” gösterdiklerini ifade etmişlerdir. Buna göre ilköğretim okullarında çalışan öğretmenlerin büyük bir çoğunluğunun (\% 76.6) yöneticilerinin dağıtımcı liderlik davranışlarının cesaretlendirme alt boyutunu gösterdiklerini düşündüğü söylenebilir. Bu bulguya dayanarak iyi iş yapıldığında, öğretmenlerin okul yöneticilerince takdir gördüklerini düşündükleri söylenebilir. Öğretmenlerin yöneticileri hakkında insanların yeteneklerine duyduğu güveni, onlara hissettirmeye önem verdikleri, grubun öğretmen liderlerini onore ettiği ve onların katkılarını desteklediği görüşünde oldukları söylenebilir.

\section{Sonuç ve Öneriler}

İlköğretim okullarında çalışan öğretmenlerin büyük bir çoğunluğu (\% 76) yöneticilerinin dağıtımcı liderlik davranışlarını gösterdiklerini düşünmektedir.

Katılımcı öğretmenlerin büyük çoğunluğu (\% 76) yöneticilerinin dağıtımcı liderlik davranışının model olma boyutunu kesinlikle katılıyorum ve katılıyorum düzeyinde gösterdiğini düşünmektedirler. 
İlköğretim okullarında çalışan öğretmenlerin çoğu tarafından (\% 67) ilköğretim okul yöneticilerinin etkileme liderlik davranışlarını kesinlikle katılıyorum ve katılıyorum düzeyinde gösterdiklerini düşünmektedirler.

İlköğretim okullarında çalışan öğretmenlerin çoğunluğu (\% 63) tarafından yöneticilerinin dağıtımcı liderlik davranışının zorluklarla başa çıkma boyutunu kesinlikle katılıyorum ve katılıyorum düzeyinde gösterdiğini düşünmektedirler.

İlköğretim okulu öğretmenlerinin büyük çoğunluğu (\% 89.4) tarafından yöneticilerin dağıtımcı liderlik davranışının imkân tanıma boyutunu kesinlikle katılıyorum ve katılıyorum düzeyinde gösterdiğini düşünmektedirler.

İlköğretim okullarında çalışan öğretmenlerin büyük bir çoğunluğunun (\% 76.6) yöneticilerinin dağıtımcı liderlik davranışlarının cesaretlendirme alt boyutunu kesinlikle katılıyorum ve katılıyorum düzeyinde gösterdiklerini düşünmektedirler.

Bu sonuçlara dayalı olarak aşağıdaki öneriler sunulabilir:

Okul yöneticilerinin öğretim liderliği davranışında model olmaları ilköğretim okullarının etkililiği açısından önemlidir. Açıkalın vd. (2007) "Okullar yöneticileri kadar okuldur” ifadesi ile okulların kurumsallaşamadığını ve yönetimlerinin okul müdürlerinin yönetim anlayışlarına göre değişen yönetim biçimleri ile karşılaşabildiklerini vurgulamaktadır. Bu açıdan öğretmenlerin büyük çoğunluğunun okul yöneticilerinin kendilerine model olduğunu düşünmeleri okul yöneticilerinin mesleki yetkinlikleri oranında okulların ve öğretmenlerin de geliştirilebileceğini düşündürmektedir. Bu nedenle sistemli ve sürekliliği olan okul müdürlerinin seçilmesi ve yetiştirilmesi konusundaki politikaların gözden geçirilmesi önem arz etmektedir. 
Okul yöneticilerinin dağıtımcı liderlik davranışlarını öğretmenlerin algısına göre değerlendirilmesinde önemli fikirler veren bu araştırmanın bazı sınırlılıkları bulunmaktadır.

Dağıtımcı liderlik, liderlik literatürüne yeni girmiş gelişmekte olan bir liderlik anlayışıdır. Bu nedenle alanda yapılan nicel araştırmaların sayısının son derece sınırlı olduğu görülmektedir. Bu çalışma da bu anlamda Türkiye'de yapılmış ilk araştırmalardan biridir. Dünyada da ulaşılabilen çalışmaların daha ziyade kavramsal tartışmalar ve nitel yöntemle yapılmış olduğu görülmüştür. Türkiye'de de bu bağlamda sadece kavramsal analiz niteliği taşıyan Baloğlu (2011)'nun araştırmasına ulaş1labilmiştir.

Henüz gelişmekte olan bir liderlik anlayışı olması nedeniyle dağımc1 liderliği ölçtüğü konusunda üzerinde anlaşılmış bir ölçek bulunmaması araştırmanın sınırlı1ıklarındandır. Ancak bazı araştırmacıların (Chen, 2007) dağıtımcı liderliği ölçmek için Kouzes ve Posner (2001) tarafından geliştirilmiş olan “Liderlik Davranışı Envanteri” isimli ölçeği kullandıkları gözlenmektedir. Bu araştırmanın verilerinin toplanmasında da bu eğilime uyularak, Kouzes ve Posner (2001) tarafından geliştirilmiş olan “Liderlik Davranışı Envanteri” isimli ölçek kullanılmıştır. Bu nedenle Türkiye'nin sosyal ve kültürel özelliklerine uygun bir ölçek geliştirilmesi önem arzetmektedir.

Ayrıca okul müdürlerinin dağıtımcı liderlik davranışlarının öğretmenler yanında öğrenciler ve veliler gibi diğer okul toplumu üyelerince nasıl algılandığı ve bu davranışların okulların etkililiğini nasıl etkilediğinin araştırılmasının Türk eğitim sistemine önem bir katkı getireceği düşünülmektedir. 


\section{Kaynakça}

Ball, J. (1997). DNA leadership through goal-driven management. VA: The Goals Institue.

Baloğlu, N. (2011). Dağıtımcı liderlik: Okullarda dikkate alınması gereken bir liderlik yaklaşımı. Ahi Evran Üniversitesi Eğitim Fakültesi Dergisi, 12(3), 127-148.

Barry, D. (1991). Managing the bossless team: Lessons in distributed leadership. Organizational Dynamics, 20, 31-47.

Bass, B. M. (1990). Handbook of leadership: Theory, research and managerial applications. New York: Free Press.

Bass. B. M. (1985). Leadership and performance beyond expectations. New York: Free Press.

Bauer, S. ve Bogotch, I. (2001). Analysis of the relationships among site council resources, council practices, and outcomes. Journal of School Leadership, 11(2), 98-119.

Bennett, N., Harvey, J.A., Wise, C. ve Woods, P.A. (2003) Desk study review of distributed leadership. Nottingham, UK: National College for School Leadership/ Centre for Educational Policy ve Management.

Bennis, W. ve Nanus. B. (1985). Leaders: The strategies for taking charge. New York: Harper and Row.

Bennis, W. (1997). Becoming a leader of leaders: Rethinking the future. London, UK: Nicholas Brealey Publishing.

Bolden, R., Petrov, G. ve Gosling, J. (2009). Distributed leadership in higher education, Educational Management Administration and Leadership, 37(2), 257-277.

Brestrich Topçu, E. (2000). Modernizmden postmodenizme dönüşümcü liderlik. Ankara: Seba Yayınları.

Brown, M. E. ve Gioia, D. A. (2002). Distributive leadership in an online division of an offline organization. The Leadership Quarterly, 13(4), 397-419.

Brown, M. H. (1989). Organizing activity in the women's movement: An example of distributed leadership, international social movement research. Greenwich CT: JAI Press. 
Brown, M. H. ve Hosking, D. M. (1986). Distributed leadership and skilled performance as successful organization in social movements. Human Relations, 39(1), 65-79.

Bryman, A. (1996). Handbook of organization studies. S. R. Clegg, C. Hardy ve W. R. Nord, (Eds.), Leadership in Organizations içinde (276-292), London: Sage.

Burns, J. M. (1998). Empowerment for change. B. Adams, W. Webster, (Eds.), Rethinking Leadership içinde (52-91), College Park: Centre for political Leadership and Participation.

Bursalığlu, Z. (2008). Okul yönetiminde yeni yapı ve davranış. Ankara: Pegem A Yayıncilik.

Camburn, E., Rowan, B. ve Taylor, J. E. (2003). Distributed leadership in schools: The case of elementary schools adopting comprehensive school reform models. Educational Evaluation and Policy Analysis, 25(4), 347-373.

Chen, G., Kirkman, B. L., Kanfer, R., Allen, D. ve Rosen, B. (2007). A multilevel study of leadership, empowerment, and performance in teams. Journal of Applied Psychology, 92 (2), 331-346.

Chen, Y. (2007). Principals' distributed leadership behaviors and their impact on student achievement in selected elementary schools in Texas. Yayınlanmamış doktora tezi, Texas A \& M University.

Chityayat, G. (1985). Working relationships between the chairman of the boards of directors and the CEO. Management International Review, 25(3), 65-70.

Clegg, S., Clarke, T. ve Ibarra, E. (2001). Millennium management, changing paradigms and organizational studies. Human Relations, 54(1), 31-36.

Committee on Human Factors (1990). Distributed decision making: Report of a workshop. Washington: National Academy Press.

Conger, J. A. ve Kanungo, R. N. (1998). Charismatic leadership in organizations. Thousve Oaks, CA: Sage.

Conger, J. A. ve Kanungo, R. N. (1987). Toward a behavioral theory of charismatic leadership in organizational settings. Academy of Management Review, 12. 637-647.

Covey, S. (1997). Putting principles first in rethinking business in rethinking the future. London, UK: Nicholas Brealey Publishing.

Çelik, V. (1999). Eğitimsel liderlik. Ankara: Pegem. 
Çetin, C. (2008). Yöneticilerin liderlik stilleri, değişim yönetimi ve ekip çalışması arasındaki ilişkilerin çok yönlü olarak değerlendirilmesi. İstanbul: İTO Yayınları.

Davis, M. W. (2009). Distributed leadership and school performance. Yayınlanmamış doktora tezi, The George Washington University.

Denis, J., Lamothe, L. ve Langley, A. (2001). The dynamics of collective leadership and strategic change in pluralistic organizations. Academy of Management Journal, 44(4), 809-837.

Dess, G. G. ve P1cken, J. C. (2000). Changing roles: Leadership in the 21 st century. Organızatıonal Dynamıcs, 28(3), 18 - 24.

Elmore, R. (2000). Building a new structure for school leadership. Washington, DC: The Albert Shanker Institute.

Erçetin, Ş. (2000). Lider sarmalında vizyon. İstanbul: Nobel Yayın.

Fry, L.W. (2003). Toward a theory of spiritual leadership. The Leadership Quarterly, 14, 693-727.

Gibb, C. A. (1954). Leadership. G. Lindzey (Eds.), Handbook of social psychology, 2 içinde (877-917). Reading, MA: Addison-Wesley.

Glen, M. (2009). Distributed leadership: A case study in a Queensland Secondary School. Yayınlanmamış doktora tezi, Faculty of Education, Griffith University.

Greenleaf, R. K. (1991). The servant as leader. Indianapolis, IN: Robert Greenleaf Center

Grint, K. (2005). Leadership: Limits and possibilities. New York: Palgrave Macmillan.

Gronn, P. (2002). Distributed leadership as a unit of analysis. The Leadership Quarterly, 13, 423-45.

Gronn, P. (1999). Substituting for leadership: The neglected role of the leadership couple. The Leadership Quarterly, 10(1), 41-62.

Gronn, P. (2000). Distributed properties: A new architecture for leadership. Educational Management Administration Leadership, 28(3), 317-338.

Gündüz, H. B., Beşoluk, Ş. ve Önder, İ. (2011). Karmaşık sistemlerde liderlik bakışıyla: DNA liderlik. Uluslararası İnsan Bilimleri Dergisi, 8 (1), 520-544. 
Hammer, M. (1997). Beyond the end of management in rethinking the future. London, UK: Nicholas Brealey Publishing.

Harman, W. (1992). 21st century business: A background for dialogue. J. Renexch (Ed.), New traditions in business: Spirit ve leadership in the 21st century içinde (10-22). San Francisco: Berrett-Koehler.

Harman, W. ve J. Hormann. (1990). Creative work: The constructive role of business in a transforming society. Indianapolis: Knowledge Systems.

Harris, A. (2005). Leading or misleading? Distributed leadership and school improvement. Journal of Curriculum Studies, 37(3), 255-265.

Harris, A. ve Muijs, D. (2005). Improving schools through teacher leadership. Maidenhead: Open University Press.

Heenan, D. A. ve. Bennis, W. (1999). Co-leaders: The power of great partnerships. New York: Wiley.

House, R. J. ve Aditya, R. N. (1997). The social scientific study of leadership: Quo Vadis? Journal of Management, 23(3), 409-473.

House, R. J. (1977). A 1976 theory of charismatic leadership. J. G. Hunt ve L. L. Larson, (Eds.), Leadership-The cutting edge içinde (189-207). Carbondale, IL: Southern Illinois University Press.

Hoy, W. ve Miskel, C. (2010). Eğitim yönetimi. (S. Turan, Çev.), Ankara: Nobel.

Hulpia, H., Devos, G. ve Rosseel, Y. (2009). Development and validation of scores on the distributed leadership inventory. Educational ve Psychological Measurement, 69(6), 1013-1034.

Hutchins, E. (1996). Cognition in the wild. Cambridge, MA: MIT Press.

Judge, W. Q. ve Ryman J. A. (2001). The shared leadership challenged in strategic alliances: Lessons from the U.S. healthcare industry. The Academy of Management Executive, 15(2), 71-79.

Karakas, F. (2009). Benevolent leadershıp, Yayınlanmamış doktora tezi, McGill University, Montreal, Canada.

Kempster S., Cope J. ve Parry, K. (2010 ). Dimensions of distributed leadership in the same context. 08.04.2011 from http://www.strath.ac.uk/media/departments/huntercentre/research/workingpapers/WP10-1_Distributed_leadership_JC_v3.pdf. 
Korkmaz, E. (2010). İlkögretim okul yöneticilerinin paylaşımcı liderlik davranışlarını gösterme düzeyleri (İzmit örneği). Yayınlanmamış yüksek lisans tezi, Sakarya Üniversitesi Sosyal Bilimler Enstitüsü.

Kouzes, J. M. ve Posner, B. Z. (1987). The leadership challenge: How to get extraordinary things done in organizations. San Francisco: Jossey-Bass.

Kouzes, J. ve Posner, B. (2001). Leadership practices inventory. San Francisco: JosseyBass.

Leithwood, K., Mascall, B., Strauss, T., Sacks, R., Memon, N. ve Yashkina, A. (2007). Distributing leadership to make schools smarter: Taking the ego out of the system. Leadership and Policy in Schools, 6(1), 37-67.

Linsky, M. ve Heifetz, R.A. (2002). Leadership on the Line: Staying alive through the dangers of leading. Cambridge: Harvard Business School Press.

Luthans, F. ve Avolio, B. J. (2003). Authentic leadership: A positive developmental approach. K. S. Cameron, J. E. Dutton, ve R. E. Quinn, (Eds.), Positive organizational scholarship içinde (241-261). San Francisco: Barrett-Koehler.

MacBeath, J., Oduro, G. K. T. ve Waterhouse, J. (2004). Distributed leadership in action: A study of current practice in schools. Nottingham: National College for School Leadership.

MacCormack, A. ve Forbath, T. (2008). Learning the fine art of global collaboration. Harvard Business Review, 86(1), 24-26.

Maltz, A. C., Shenhar, A. J. ve Reilly, R. R. (2003). Beyond the balanced scorecard: refining the search for organizational success measures. Long Range Planning, 36 (2), 187-204.

Marion, R. ve Uhl-Bien, M. (2001). Leadership in complex organizations. The Leadership Quarterly, 12(4), 389-418.

Miller, E. J. (1998). The leader with the vision: is time running out? E. B. Klein, F. Gabelnick, ve P. Herr (Eds.), The psychodynamics of leadership içinde (3-25). Madison, CT: Psychosocial Press.

Murphy, J. ve Beck, L. G. (1995). School-based management as school reform: Taking stock. CA : Corwin Press.

O'Grady, T. P. ve Malloch, K. (2007). Quantum leadership : A resource for healt care 
ınnovation. London: Jones ve Barlett Publishers.

Özçimenli, E., Güleş, H. ve Turan, S. (2011). Çoğulcu liderlik: Kavramsal bir çözümleme, VI Ulusal Eğitim Yönetimi Kongresi, Magosa, KKTC, (16-17 Nisan).

Parry, K.W. ve Hansen, H. (2007). The organizational story as leadership. The Leadership Quarterly, 3 (3), 301-324.

Pearce, C.L. ve Conger, J.A. (2003). Shared leadership: Reframing the hows ve whys of leadership. Thousve Oaks: Sage.

Pye, A. (2005). Leadership ve organizing: Sense-making in action. Leadership, 1 (1), $31-50$.

Ray, M. ve Rinzler, A. (1993). The new paradigms in business. New York: Tarcher/ Putnam.

Sergiovanni, T. (1995). The principalship: A reflective practice perspective. Boston: Allyn and Bacon.

Shamir, B., House, R. J. ve Arthur, M. B. (1993). The motivational effects of charismatic leadership: A self-concept based theory. Organization Science, 4 (4), 577-594.

Spears, L. C. (2004). The understanding and practice of servant leadership. L.C. Spears, M. Lawrence, (Eds.), Practicing Servant-leadership: Succeeding through trust, bravery, and forgiveness içinde (167-200). San Francisco, CA: Jossey-Bass.

Spillane J. P. (2003). Educational Leadership. Educational Evaluation and Policy Analysis, 25(4), 343-346.

Spillane, J. P. (2006). Distributed Leadership. San Francisco: Jossey-Bass.

Spillane, J. P. ve Diamond, J. B. (2007). Distributed leadership in practice. New York: Teachers College Press.

Spillane, J. P., ve Healey, K. (2010). Conceptualizing school leadership and management from a distributed perspective. The Elementary School Journal, 111(2), 253 - 281.

Spillane, J. P., Camburn, E. M. ve Pareja, A. S. (2007). Taking a distributed perspective to the school principal's workday. Leadership and Policy in Schools, 6(1), 103-125.

Spillane, J. P., Diamond, J. B. ve Jita, L. (2003). Leading instruction: The distribution of leadership for instruction. Journal of Curriculum Studies, 35(5), 533-543.

Spillane, J. P., Halverson, R. ve Diamond, J. B. (2001). Investigating school leadership 
practice: A distributed perspective. Educational Researcher, 30(3), 23-28.

Spillane, J. P., Halverson, R. ve Diamond, J. B. (2004). Towards a theory of leadership practice: A distributed perspective. Journal of Curriculum Studies, 36(1), 3-34.

Spillane, J. P., Hunt, B. ve Healey, K. (2009). Managing and leading elementary schools: Attending to the formal and informal organisation. International Studies in Educational Administration,37(1), 5-28.

Stewart, R. (1991 a). Chairmen and chief executives: An exploration of their relationship. Journal of Management Studies, 28(5), 511-527.

Storey, A. (2004), The problem of distributed leadership in schools, School Leadership and Management, 24(3), 249-265.

Şişman, M. (2002 b). Öğretim liderliği. Ankara: Pegem A Yayıncılık.

Timperley, H. S. (2005). Distributed leadership: Developing theory from practice. Journal of Curriculum Studies, 37(4), 395-420.

Uhl-Bien, M., Mrion, R. ve McKelvey, B. (2007). Complexity leadership theory: Shifting leadership from the industrial age to the knowledge era. The Leadership Quarterly, 18 (4), 298-318.

Wheatley, M. (1992). Leadership and the new science. San Francisco: Berrett-Koehler.

Yukl, G. (1999). An evaluation of conceptual weaknesses in transformational and charismatic leadership theories. Leadership Quarterly, 10(2), 285-305.

Yukl, G. A. (1989). Leadership in organizations. Englewood Cliffs, NJ: Prentice Hall.

Yukl, G. A. (2002). Leadership in organizations. New Jersey: Prentice Hall. 